PTNSS-2008-SS3-307

\title{
New ship propulsion engines in production by HCP-Company
}

\section{Nowe silniki napędu okrętowego produkowane przez firmę H.Cegielski-Poznań SA}

The H. Cegielski Poznań SA (HCP) company from Greater Poland has been known on the home and foreign markets for over 168 years. For more than 50 years, it has been reckoned among companies possessing the MAN DIESEL A/S and Wärtsilä licences to manufacture, among other products, two-stroke engines. During that time, H.Cegielski Poznań SA has produced over 1500 engines totalling to $13,800,000 \mathrm{~kW}^{1)}$.

In recent months the company has joined the group of manufacturers producing the electronically-controlled en-
Wielkopolska firma H.Cegielski-Poznań SA (HCP) jest znana na rynku krajowym i zagranicznym od ponad 168 lat. Od ponad 50. lat jest w gronie kilkunastu firm mających licencje MAN DIESEL A/S i Wärtsilä na produkcję między innymi silników dwusuwowych. W tym czasie zakład wyprodukował ponad 1500 silników o łącznej mocy $13800000 \mathrm{~kW}$.

W ostatnich miesiącach 2008 r. firma dołączyła do grona producentów silników elektronicznych. Dnia 11 lipca 2007 odbyła się próba zdawcza pierwszego z kilku zamówionych

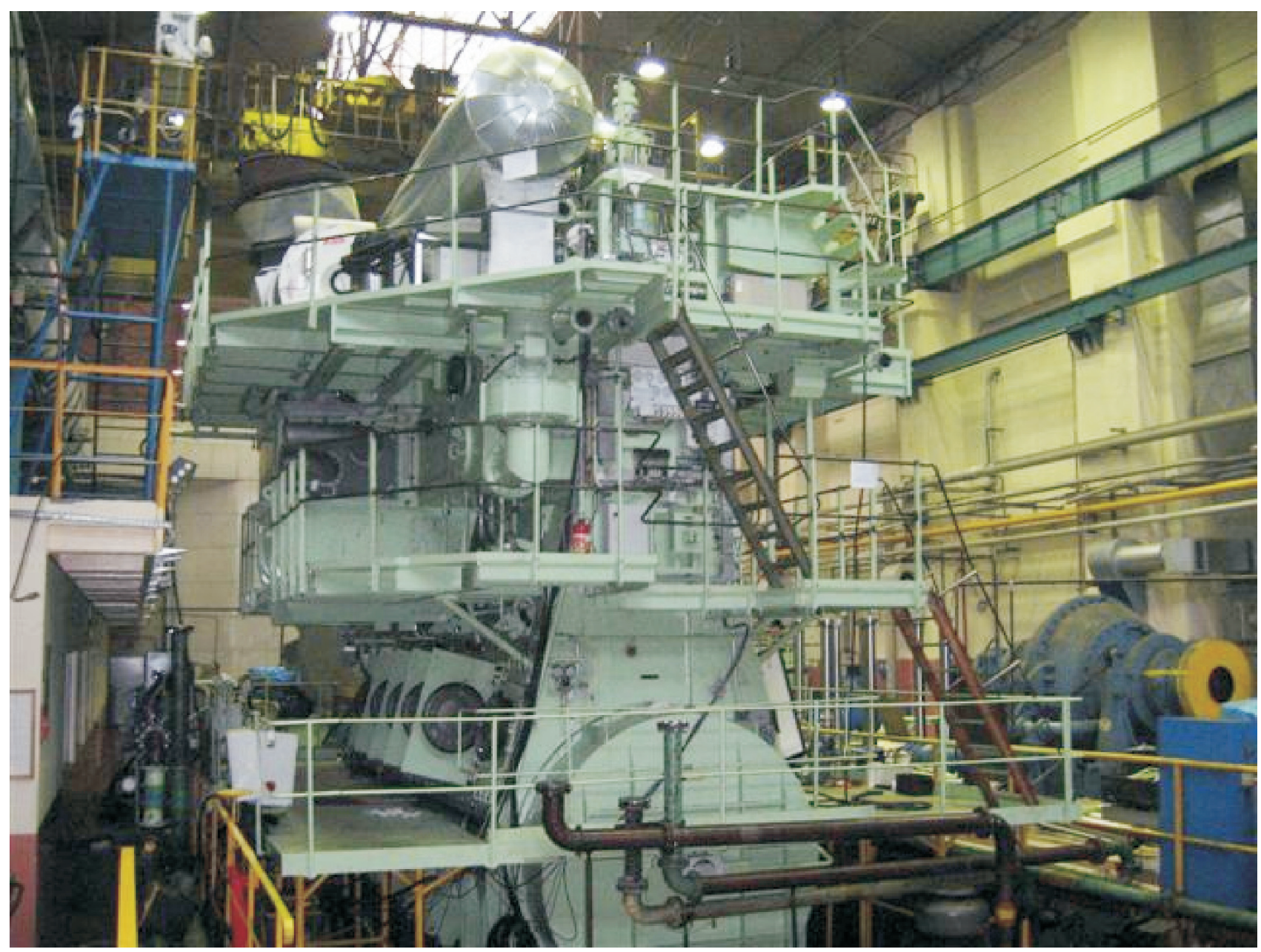

gines. On July 11, 2007, the first of a few 7RT-flex50-B-type engines ordered by Wärtsilä was the subject of the delivery test. It is a 7-cylinder engine rating a power of $11620 \mathrm{~kW}$

1) More information abort marine engines production in $\mathrm{HCP}$ can be found in the Combustion Engines Magazine (Silniki Spalinowe) No.: 1/2004 (118) and 3/2006 (126). przez firmę Wärtsilä silników typu 7RT flex50-B. Jest to silnik 7-cylindrowy o mocy $11620 \mathrm{~kW}$ (1660 kW/cyl.), $124 \mathrm{obr} / \mathrm{min}$ i średnim ciśnieniu użytecznym 20 bar. Typową dla silnika „mechanicznego” konfigurację pomp wtryskowych paliwa i napędu zaworów za pośrednictwem wału rozrządu i przekładni zębatej zastąpiono układem pomp zasilających w zespole zasilania i szyną common rail (ciśnienie 
(1660 kW/cyl.), engine speed of $124 \mathrm{rpm}$ and mean effective pressure of 20 bar. The configuration, typical for "mechanical" engine with fuel injection pumps and valve drives by camshaft and gear transmission is replaced by a compact set of supply pumps in the supply unit and the common rail (pressure inside the rail 1000 bar) with the integrated electronic system of WECS-9520 type (Wärtsilä Engine Control System). All functions on the engine including fuel injection, exhaust valve drives, the timing of the injection and more are fully under electronic control.

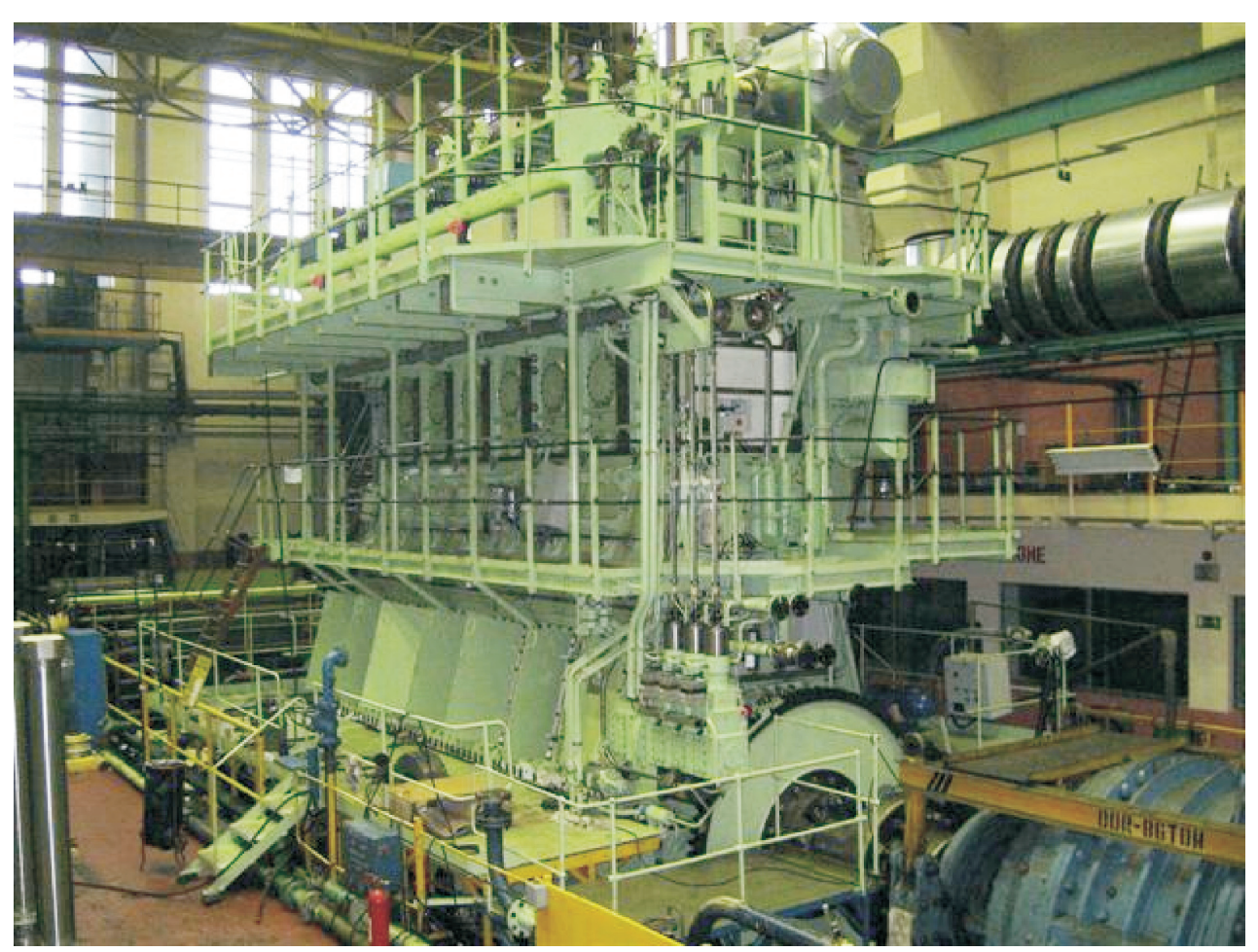

wewnątrz szyny wynosi 1000 barów) wraz z zintegrowanym układem elektronicznym typu WECS-9520 (układ sterowania silnikiem firmy Wärtsilä). Wszystkie działania w silniku, w tym wtrysk paliwa, napęd zaworów wydechowych, rozrząd i inne są sterowane w pełni elektronicznie.

7 stycznia 2008 r. odbyła się w Poznaniu próba zdawcza produkowanego na licencji MAN DIESEL A/S silnika 7S60ME-C. Jest to silnik 7-cylindrowy o mocy $15820 \mathrm{~kW}$, $105 \mathrm{obr} / \mathrm{min}$ i średnim ciśnieniu użytecznym 19.0 bar. Silnik ten jest przeznaczony do napędu car carrier (6000 cars) budowanego w Stoczni Gdynia SA dla armatora Rami Ungar (jest to kontynuacja serii, na których poprzednio był stosowany silnik 7S60MC-C; stocznia zamówiła dotychczas 11 silników ME-C plus $1 \mathrm{w}$ opcji).

W koncepcji silników ME występuje układ hydrauliczno-mechaniczny do aktywowania wtrysku paliwa i zaworów wydechowych. Aktuatorami steruje elektronicznie wiele zespołów tworzących kompletny Układ Sterowania Silnikiem. Pompa paliwowa składa się z prostego tłoka napędzanego tłokiem hydraulicznym uruchamianym pod wpływem ciśnienia oleju, którym steruje elektroniczny zawór proporcjonalny. Zawór wydechowy jest otwierany

On January 7, 2008, a 7S60ME-C engine manufactured under the MAN DIESEL A/S licence was put to delivery test in Poznań. It is a 7-cylinder engine rating a power of $15,820 \mathrm{~kW}$ at $105 \mathrm{rpm}$ and mean effective pressure of 19.0 bar. The engine is intended for the propulsion of a car carrier (6000 cars) built at Stocznia Gdynia SA for Mr. Rami Ungar - Shipowner (it is a continuation of the series on which the 7S60MC-C engine was used previously; the Shipyard has ordered so far eleven ME-C engines plus one in option). The ME engine concept consists of a hydraulicmechanical system for activation of the fuel injection and the exhaust valves. The actuators are electronically controlled by a number of control units forming the complete Engine Control System. The fuel pressure booster consists of a simple plunger powered by a hydraulic piston activated by oil pressure. The oil pressure is controlled by an electronically-controlled proportional valve. The exhaust valve is opened hydraulically, just as on the MC-series engines, but the camshaft-driven mechanical actuator is replaced by a two-stage exhaust valve actuator activated by the control oil from an electronically-controlled proportional valve. hydraulicznie, podobnie jak w silnikach MC, ale mechaniczny aktuator napędzany przez wał rozrządu zastąpiono dwustopniowym mechanizmem napędu zaworu wydechowego, aktywowanym olejem sterującym z elektronicznego zaworu proporcjonalnego.

Zalety silników typu ME i flex:

- mniejsze jednostkowe zużycie paliwa i lepsze parametry pracy dzięki zmiennemu, elektronicznie sterowanemu rozrządowi wtrysku paliwa i zaworów wydechowych przy dowolnym obciążeniu,

- polepszona charakterystyka emisji spalin, z niższą emisją $\mathrm{NO}_{x}$ i pracą bez dymu,

- przystosowanie do różnych trybów pracy,

- korzyści w odniesieniu do kosztów eksploatacyjnych i wymagań w zakresie konserwacji,

- możliwa mniejsza prędkość obrotowa manewrowa,

- niewielkie zmniejszenie ciężaru silnika w porównaniu z silnikami „mechanicznymi”.

Firma H. Cegielski-Poznań S.A. jest przygotowana do produkcji pełnego typoszeregu silników, zarówno konstrukcji Wärtsilä, jak i MAN DIESELA/S. Ograniczenia produkcyjne, które występują w firmie sprowadzają się do transportu 
The advantages of the ME-series and flex engines are:

- Lower SFOC (Specific Fuel Oil Consumption) and better performance parameters thanks to variable electronicallycontrolled timing of fuel injection and exhaust valve at any load.

- Improved emission characteristics, with lower $\mathrm{NO}_{x}$ and smokeless operation.

- Adaptation to different operating modes.

- Benefits in terms of operating costs, maintenance requirement.

- Lower speeds are possible for manoeuvring.

- Slight reduction of engine mass, compared to "mechanical" engines.

H. Cegielski Poznań S.A. is able to manufacture the full series of engine types, designed both by Wärtsilä and MAN DIESELA/S. Production limits occurring in the company boil down to the transportation of large engine components, lifting capacity of overhead cranes, as well as possibility to carry away tested engine heat. $\mathrm{HCP}$ can manufacture engines of $820 \mathrm{~mm}$ bore and $31,000 \mathrm{~kW}$ power. At present the engine $7 \mathrm{~K} 80 \mathrm{MC}-\mathrm{C}$ (24 engines have been made until now) with an increased power of $26,270 \mathrm{~kW}$ is the biggest engine produced by the company.

H. Cegielski Poznań SA's scope of production is not limited only to the manufacture of two-stroke

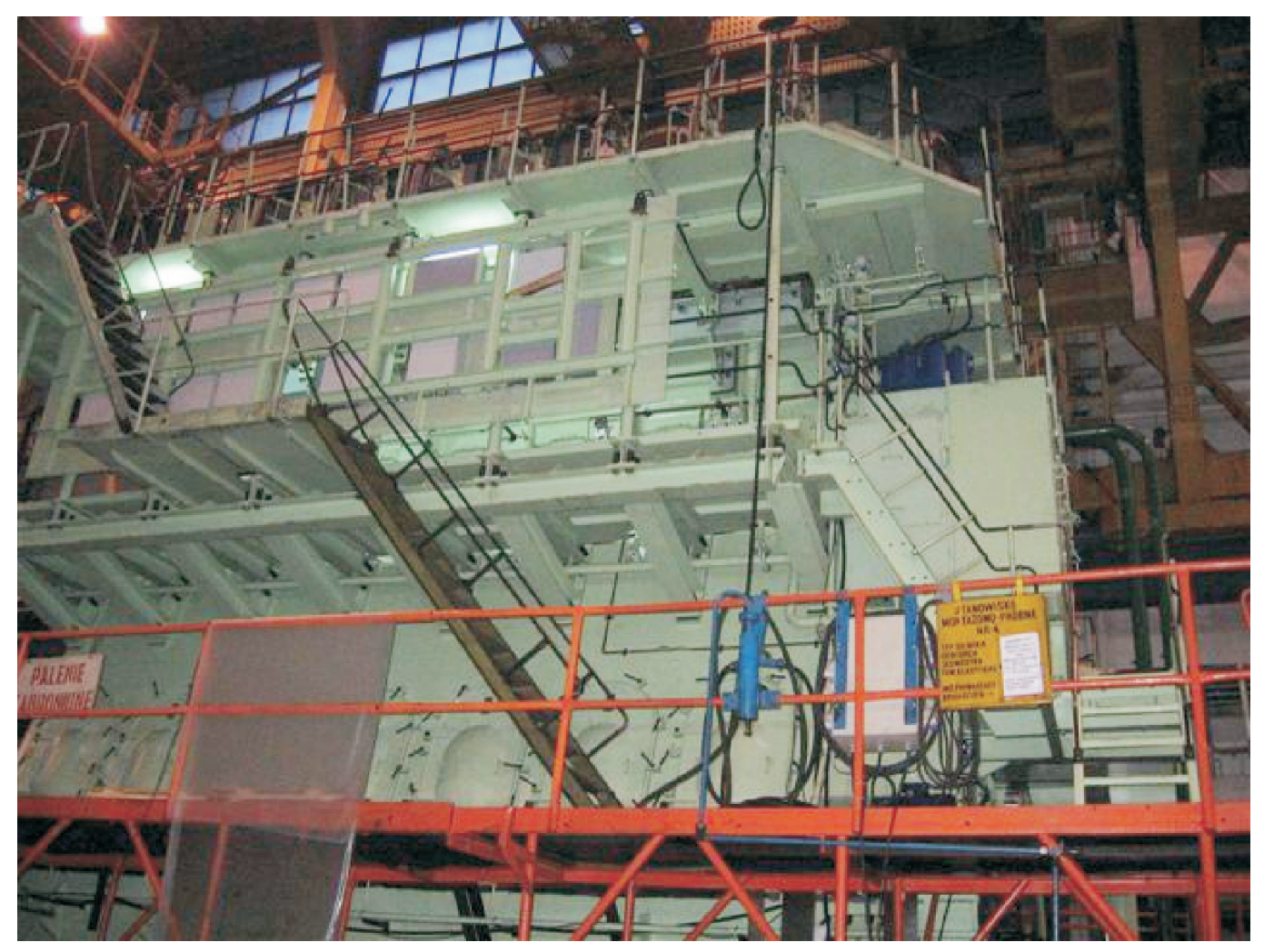

wielkogabarytowych komponentów silnika, udźwigu suwnic oraz możliwości odprowadzenia ciepła hamowanego silnika. HCP może produkować silniki do średnicy $820 \mathrm{~mm}$ i mocy $31000 \mathrm{~kW}$. Obecnie największym produkowanym przez firmę jest silnik 7K80MC-C (wyprodukowano dotychczas 24 silniki) o podniesionej mocy $26270 \mathrm{~kW}$.

Zakres produkcji HCP nie ogranicza się tylko do silników dwusuwowych napędu głównego statków. Na przełomie lat 80. i 90. XX wieku firma dostarczyła na Wyspy Greckie wiele siłowni wyposażonych w silniki stacjonarne produkowane na licencji firmy Wärtsilä (dawniej Sulzer). Obecnie firma realizuje kontrakt na dostawę siłowni o mocy $4520 \mathrm{~kW}$ do Brake w Niemczech (z wyjątkiem budynku dostawa obejmuje silnik, prądnicę, całe wyposażenie siłowni, osprzęt, rury). Jednostka napędowa engines intended for

ship propulsion. At the turn of the 1980s the company delivered to the Greek Islands a number of power-plants with stationary engines produced under the Wärtsilä (former Sulzer) license. Now, the company is performing the contract for the delivery of a power plant of $4520 \mathrm{~kW}$ to Brake in Germany (except for building, the delivery includes engine, generator, all plant equipment, fittings, pipes). The driving unit is a 7L35MC-S engine $\left(\mathrm{N}_{\mathrm{e}}=4520 \mathrm{~kW}\right.$ at $\left.214.3 \mathrm{rpm}\right)$ under the MAN DIESEL license. It is the first power plant in the world, where a two-stroke engine will be operating on crude palm oil. The requirement for operation on biofuel made it necessary to implement modifications both in materials used for the production of engine elements having contact with that fuel oil, and in engine design (fuel pump, camshaft). 